\title{
Caddo Ceramic Vessel Sherds in a 2004 Surface Collection from the Sanders Site (41LR2), Lamar County, Texas
}

Timothy K. Perttula

Heritage Research Center, Stephen F. Austin State University

Mark Walters

Heritage Research Center, Stephen F. Austin State University

Follow this and additional works at: https://scholarworks.sfasu.edu/ita

Part of the American Material Culture Commons, Archaeological Anthropology Commons, Environmental Studies Commons, Other American Studies Commons, Other Arts and Humanities Commons, Other History of Art, Architecture, and Archaeology Commons, and the United States History Commons

Tell us how this article helped you.

This Article is brought to you for free and open access by the Center for Regional Heritage Research at SFA ScholarWorks. It has been accepted for inclusion in Index of Texas Archaeology: Open Access Gray Literature from the Lone Star State by an authorized editor of SFA ScholarWorks. For more information, please contact cdsscholarworks@sfasu.edu. 
Caddo Ceramic Vessel Sherds in a 2004 Surface Collection from the Sanders Site (41LR2), Lamar County, Texas

\section{Creative Commons License}

\section{(c) (1) (8)}

This work is licensed under a Creative Commons Attribution-NonCommercial 4.0 International License 


\title{
Caddo Ceramic Vessel Sherds in a 2004 Surface Collection from the Sanders Site (41LR2), Lamar County, Texas
}

\author{
Timothy K. Perttula and Mark Walters
}

\section{Introduction}

The T. M. Sanders site (41LR2) is one of the more important ancestral Caddo sites known in East Texas, primarily because of its two earthen mounds and the well-preserved mortuary features of Caddo elite persons buried in Mound No. 1 (the East Mound), as well as its extensive (200+ acres) habitation deposits and material culture remains of the Middle Caddo and Historic Caddo period components (Hamilton 1997; Jackson et al. 2000; Krieger 1946, 2000; Perttula et al. 2015; Wilson 1995). The T. M. Sanders site is located on a broad alluvial terrace just south of the confluence of Bois d'Arc Creek and the Red River (Figure 1).

\section{Ceramic Vessel Sherd Sample}

In recent years, several assemblages of ancestral Caddo sherds from the T. M. Sanders site have been analyzed to better understand their temporal, stylistic, and technological character (see Perttula 2013; Perttula and Nelson 2016; Perttula et al. 2015). The 78 Caddo ceramic vessels in the Texas Archeological Research Laboratory collections have also been re-documented (Perttula et al. 2016). This article continues this trend, as it concerns the analysis of a small sample of plain and decorated sherds that was collected from the surface of the site in November 2004, but heretofore unstudied.

The 92 ceramic vessel sherds in this sample from the T. M. Sanders site are from plain, utility, and fine ware vessels (Table 1). About 85 percent of the sherds are from grog-tempered vessels, and the remainder are from bone-tempered vessels. The bone-tempered sherds are particularly prominent (80 percent) in the utility ware vessels, compared to 14 percent in the fine wares and 11 percent in the plain ware sherds.

Table 1. Ceramic wares in the 2004 sample of sherds from the T. M. Sanders site.

\begin{tabular}{lccl}
\hline Ware & Grog-tempered & Bone-tempered & N \\
\hline Plain & 71 & 9 & 80 \\
Utility & 1 & 4 & 5 \\
Fine & 6 & 1 & 7 \\
\hline Totals & 78 & 14 & 92 \\
\hline
\end{tabular}

In the case of the non-slipped plain grog-and/or bone-tempered sherds and vessels from the T. M. Sander site that had been subsumed within either earlier Sanders Plain or Paris Plain (see Brown 1996) typological labels, Perttula et al. (2016) have redefined them as Bois d'Arc Plain. The 80 plain sherds are all from Bois d'Arc Plain vessels. The plain to decorated sherd ratio in this assemblage is 6.67. Fine wares comprise 58 percent of the decorated sherds (see Table 1). 


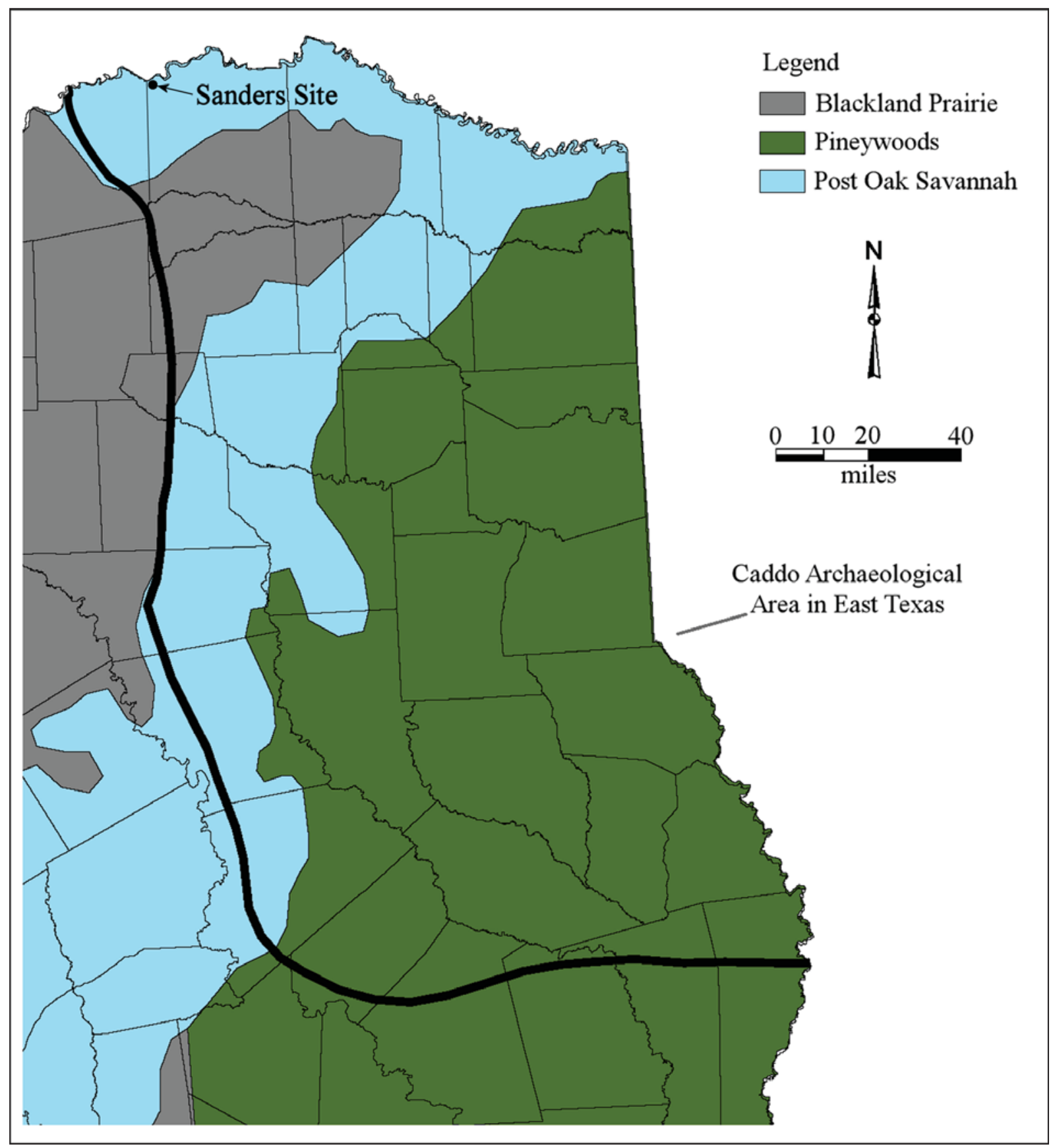

Figure 1. The location of the T. M. Sanders site in East Texas.

One Sanders Incised body sherd with diagonal opposed lines (see Perttula et al. 2016) is in the utility wares, along with a bone-tempered body sherd with tool punctated rows. Two bone-tempered fingernail punctated sherds (Figure 2) are from Monkstown Fingernail Impressed vessels (see Suhm and Jelks 1962). Both utility ware types are amongst the defined ceramic types in the Middle Caddo period component at the T. M. Sanders site (Perttula et al. 2016:Table 2). The one remaining utility ware sherd has a row of fingernail punctations above a horizontal brushing zone.

One of the fine ware sherds has opposed engraved lines, and may be from a Sanders Engraved vessel. A second engraved sherd has a single curvilinear engraved line. Five of the seven fine ware sherds in this sherd assemblage have a red slip on either one or both sherd surfaces, and they are from carinated bowls and bottles. As redefined by Brown (1996:401-403 and Figures 2-191, 2-34g, 2-37a-1, 2-38d, 2-39d, k, 


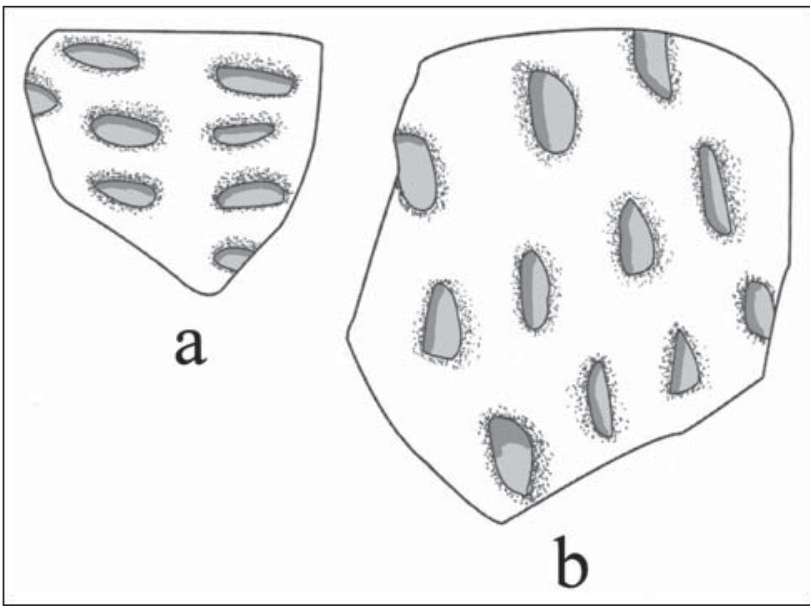

Figure 2. Monkstown Fingernail Impressed body sherds from the T. M. Sanders site. n-q, and 2-42b), Sanders Plain was considered a grog-tempered, slipped, and undecorated type found widely across the Caddo area. Vessel forms include bowls, carinated bowls, and narrow, and wide-mouthed bottles. Because the key attribute of the Sanders Plain type was the fact that vessels of the type had slipped surfaces, rather than that they were plain, based on the re-analysis of the ceramic vessels from the Sanders site, Perttula et al. (2016) have renamed the type as Sanders Slipped, so that there is no confusion about the decorative elements represented in this type. Sanders Engraved and Sanders Slipped are among the principal fine ware types in the Middle Caddo period component at the T. M. Sanders site (Perttula et al. 2016:Table 2), along with Maxey Noded Redware.

\section{Summary and Conclusions}

A sample of 92 plain, utility, and fine ware sherds were collected from the surface of the T. M. Sanders site (41LR2) in November 2004, but remained unstudied until now. The assemblage of sherds is from the extensive Middle Caddo period occupation of the site, and includes sherds from grog- and bonetempered Bois d'Arc Plain, Sanders Incised, Monkstown Fingernail Impressed, Sanders Engraved, and Sanders Slipped vessels. These vessels include jars, bottles, and carinated bowls.

\section{Acknowledgments}

Lance Trask prepared the figures for this article.

\section{References Cited}

Brown, J. A.

1996 The Spiro Ceremonial Center: The Archaeology of Arkansas Valley Caddoan Culture in Eastern Oklahoma. 2 Vols. Memoirs No. 29. Museum of Anthropology, The University of Michigan, Ann Arbor.

Hamilton, D. L.

1997 Observations on Caddoan Burial Practices at the Sanders Site (41LR2). Bulletin of the Texas Archeological Society 68:115-134.

Jackson, A. T., M. S. Goldstein, and A. D. Krieger

2000 The 1931 Excavations at the Sanders Site, Lamar County, Texas: Notes on the Fieldwork, Human Osteology, and Ceramics. Archival Series 2. Texas Archeological Research Laboratory, The University of Texas at Austin.

Krieger, A. D.

1946 Culture Complexes and Chronology in Northern Texas, with Extensions of Puebloan Datings to the Mississippi Valley. Publication No. 4640. The University of Texas, Austin.

2000 The Pottery of the Sanders Farm. In The 1931 Excavations at the Sanders Site, Lamar County, Texas: Notes on the Fieldwork, Human Osteology, and Ceramics, by A. T. Jackson, M. S. Goldstein, and A. D. Krieger, pp. 131-144. Archival Series 2. Texas Archeological Research Laboratory, The University of Texas at Austin. 
Perttula, T. K.

2013 Analysis of a Small Sample of Caddo Ceramic Sherds from the T. M. Sanders Site (41LR2), Lamar County, Texas. Journal of Northeast Texas Archaeology 39:1-5.

Perttula, T. K. and B. Nelson

2016 Further Surface Collecting and Shovel Testing Investigations at the Sanders Site (41LR2), Lamar County, Texas. Journal of Northeast Texas Archaeology 60:53-65.

Perttula, T. K., B. Nelson, M. Walters, and R. Z. Selden Jr.

2015 The Sanders Site (41IR2): A Middle to Historic Caddo Settlement and Mound Center on the Red River in Lamar County, Texas. Journal of Northeast Texas Archaeology 50:1-87.

Perttula, T. K., M. Walters, and B. Nelson

2016 Caddo Ceramic Vessels from the T. M. Sanders Site (41LR2) on the Red River in Lamar County, Texas. Special Publication No. 41. Friends of Northeast Texas Archaeology, Austin and Pittsburg.

Suhm, D. A. and E. B. Jelks (editor)

1962 Handbook of Texas Archeology: Type Descriptions. Special Publication No. 1, Texas Archeological Society, and Bulletin No. 4, Texas Memorial Museum, Austin.

Wilson, D.

1995 Dental Paleopathologies in the Sanders Site (41LR2) Population from Lamar County. Journal of Northeast Texas Archaeology 5:29-59. 